\title{
Do School Advisors Contribute to the Teachers' Professional Development? A Greek Case Study
}

\author{
Dr George N. Vozaitis (Corresponding author) \\ Secondary School Teacher \\ Department of Educational Sciences and Early Childhood Education \\ University of Patras, Rio, Patras 26504, Greece \\ E-mail: vozaitis@upatras.gr \\ Amalia A. Ifanti \\ Professor of Educational Planning and Policy \\ Department of Educational Sciences and Early Childhood Education \\ University of Patras, Rio, Patras 26504, Greece \\ E-mail: ifanti@upatras.gr
}

Received: August 7, 2017 Accepted: August 24, 2017 Online published: September 1, 2017 doi:10.5296/jpag.v7i3.11771 URL: https://doi.org/10.5296/jpag.v7i3.11771

\begin{abstract}
This empirical study investigates the contribution of Secondary Education School Advisors to the professional development of teachers at the same level. For this purpose, 34 Secondary Education School Advisors of the Regional Directorate of Primary and Secondary Education of Western Greece were interviewed. Semi-structured interviews were employed aiming to explore the School Advisors' contribution to the professional development of teachers. Data analysis revealed that, although the School Advisors attached great importance to their role in the professional development of teachers, they quoted the various problems that have been linked to their role over time and indicated the requirements for the progress and further development of the institution in the future.
\end{abstract}

Keywords: School Advisor, secondary education, teacher, professional development, Greece 1. Introduction

It is widely admitted that the professional development of teachers constitutes an ongoing 
process of interaction between formal and informal learning experiences, reinforcement of their knowledge and skills and improvement of their working experience in order to promote learning and the overall progress of students (Bubb \& Early, 2010). Since the 1970s and 1980s, professional development has been associated with activities of life-long learning for teachers and of the support of the school organization, aiming at school's improvement and the teachers' personal and professional development, so that the latter acquire self-knowledge, professional maturity and autonomy (Davies \& Ellison, 2001; Pashiardis, 2009; Schein, 1992; Sergiovanni, 1984; York-Barr \& Duke, 2004). Professional development has drastically affected the increase of school effectiveness, fortifying significant aspects of education, such as learning conditions, the evaluation of students and the design of the curriculum. Concurrently, it constituted a lever for wider internal changes in school (Avalos, 2011; Bush, 2009; Maslowski et al., 2008; Robinson \& Timperley, 2007; Shawer, 2010; Tang et al., 2010).

In addition, in recent years, the professional development of teachers is correlated more and more with the formation of their professional identity, whose construction gives prominence to the role of their experiences, particularly in the early stages of their professional life (Beijaard et al., 2004; Day et al., 2006; Flores \& Day, 2006; Hilferty, 2008; Ifanti \& Fotopoulou, 2011; Kelchtermans, 2005; Swann et al., 2010).

The dynamics of the personal experiences of teachers in shaping their professional identity is undoubtedly linked to school culture. Several works on the professional development of teachers accentuate the importance of a supportive environment in the school place, in which interaction with other teachers as well as cooperation among them is fostered. Consequently, the choice of issues for investigation on the part of teachers and the search for solutions to everyday problems arising at school on the basis of educational research and teachers' active involvement in it are encouraged (Aas, 2016; Fullan, 2001; Kirk, 2004; MacBeath et al., 2000; MacBeath \& Moos, 2004; MacGilchrist et al., 2008).

Current trends in the field of professional development have highlighted the development of school and teachers in such a way that individual needs along with those of school are successfully met. Teachers as individuals and schools as learning organizations are required to transform their practices, with a view to adapting effectively to the new socio-economic data.

In the Greek educational system, which stands out for its centralized character (Ifanti, 1994, 2009) from the 1980s, the administrative responsibilities of the officials in school education were separated from the guiding ones (see: Law 1304/1982). Administrative duties were assigned to school principals, while School Advisors were assigned the pedagogical guidance of teachers, participating institutionally in the development and professional growth of the latter but also playing a decisive role in strengthening the school. The last effort to decentralize the Greek educational system was undertaken with Law 2817/2000, when the Regional Education Directorates in the headquarters of the relevant regions of the country were established, which assumed the implementation and monitoring of the central educational policy at a local level. This legislative regulation also affected the responsibilities of School Advisors, since, along with other officials in education, they appertained 
administratively to the control and superintendence of the Regional Directors. More specifically, with the enactment of Law 2986/2002, all School Advisors (of preschool, primary, secondary, and special education) were placed in the administrative competence of the respective Regional Education Directorates. In every regional Directorate of Education, except for the Department of Administration, Departments of Scientific-Pedagogical Guidance were established as well, one for each level of education, which were responsible for the coordination and support of the work of School Advisors. Despite all legislative regulations, the control of the educational system maintained its centralized nature affecting inevitably the operation of the School Advisor in its institutional framework.

This paper deals with the issue of the contribution of School Advisors of secondary education to the professional development of teachers. In particular, we investigate the multifaceted role of School Advisors as special educators-consultants and as key personnel in education in order to demonstrate various aspects of their work which are crucial for the professional development of teachers and school improvement altogether.

\section{Material and Method}

Research data were collected from semi-structured interviews (see, for instance, Cohen et al., 2008: 458; Mason, 2003: 83-131, Robson, 2007: 330), which were conducted with the secondary education School Advisors of the Regional Education Directorate of Western Greece. The total population of School Advisors was forty-two (42). Of them, two (2) School Advisors, who were randomly chosen, participated in the pilot study which preceded, and as a result, they were not included in the final survey. Subsequently, of the forty (40) School Advisors, thirty-four (34) responded (participation rate: 85\%).

The questionnaire of the interviews consisted of fourteen (14) questions in total and was divided into two parts. The first part was related to the demographic characteristics of the sample and was analyzed in six (6) individual sub-questions linked to gender, specialty, regional units, further studies, the overall educational service and the years of serving as School Advisors.

In view of the optimum processing of the data, the specialty as well as further studies were grouped onwards (see Table 1). Additionally, through the criterion $\mathrm{x} 2$, the demographic characteristics of School Advisors were correlated with the categorical variables, namely gender, specialty, the total years of educational service and the years of their performance as School Advisors. This correlation was only associated with questions 3a, 3b, 3c, 4a, 4b, 4c, $4 \mathrm{~d}, 4 \mathrm{e}, 5,6 \mathrm{a}, 6 \mathrm{~b}$ and 8 , to which the responses of School Advisors were unique. The technique of content analysis was used, modeling specific categories on the basis of the above questions (Kyriazi, 2002: 283; Vamvoukas, 2010: 269).

\section{The Research Data}

Of the total 34 participants in the survey, nineteen (19) School Advisors were men (55.88\%) and fifteen (15) were women (44.12\%). Regarding their specialties, sixteen (16) School Advisors (47.06\%) belonged to the group of Humanities and Social-Political Sciences and eighteen (18) School Advisors (52.94\%) to that of Applied Sciences. Regarding their regional 
units, eighteen (18) School Advisors held office in the Regional unit of Aetolia-Acarnania (52.94\%), twenty-one (21) in the Regional unit of Achaia (61.76\%), sixteen (16) in the Regional unit of Elis (47.06\%) and fourteen (14) in other regional units outside the area of Western Greece under investigation (41.18\%).

Concerning their studies, twenty six (26) School Advisors held a Master degree (76.47\%), nineteen (19) had a $\mathrm{PhD}$ degree (55.88\%), fifteen (15) had god a second university degree (44.11\%) and three (3) had completed the annual training certificate at the In-Service Secondary Teachers Training School $(8.82 \%)$. Of the School Advisors in the sample, one (1) had professional experience of 12-20 years (2.94\%), nine (9) had a total educational experience from $20+$ to 25 years $(26.48 \%)$, twelve (12) from $25+$ to 30 years $(35.29 \%$ ) and twelve (12) from $30+$ to 38 years $(35.29 \%)$. With regard to the total years on their duty as School Advisors, three (3) had seniority from one month to one year in the institution $(8.82 \%)$, fourteen (14) from $1+$ to 5 years $(41.18 \%)$, eleven (11) from $5+$ to 10 years $(32.35 \%)$ and six (6) had served from $10+$ to 16 years $(17.65 \%)$. In the following table, the grouped demographic characteristics of School Advisors are briefly presented.

Table 1. Grouped demographic characteristics of the sample

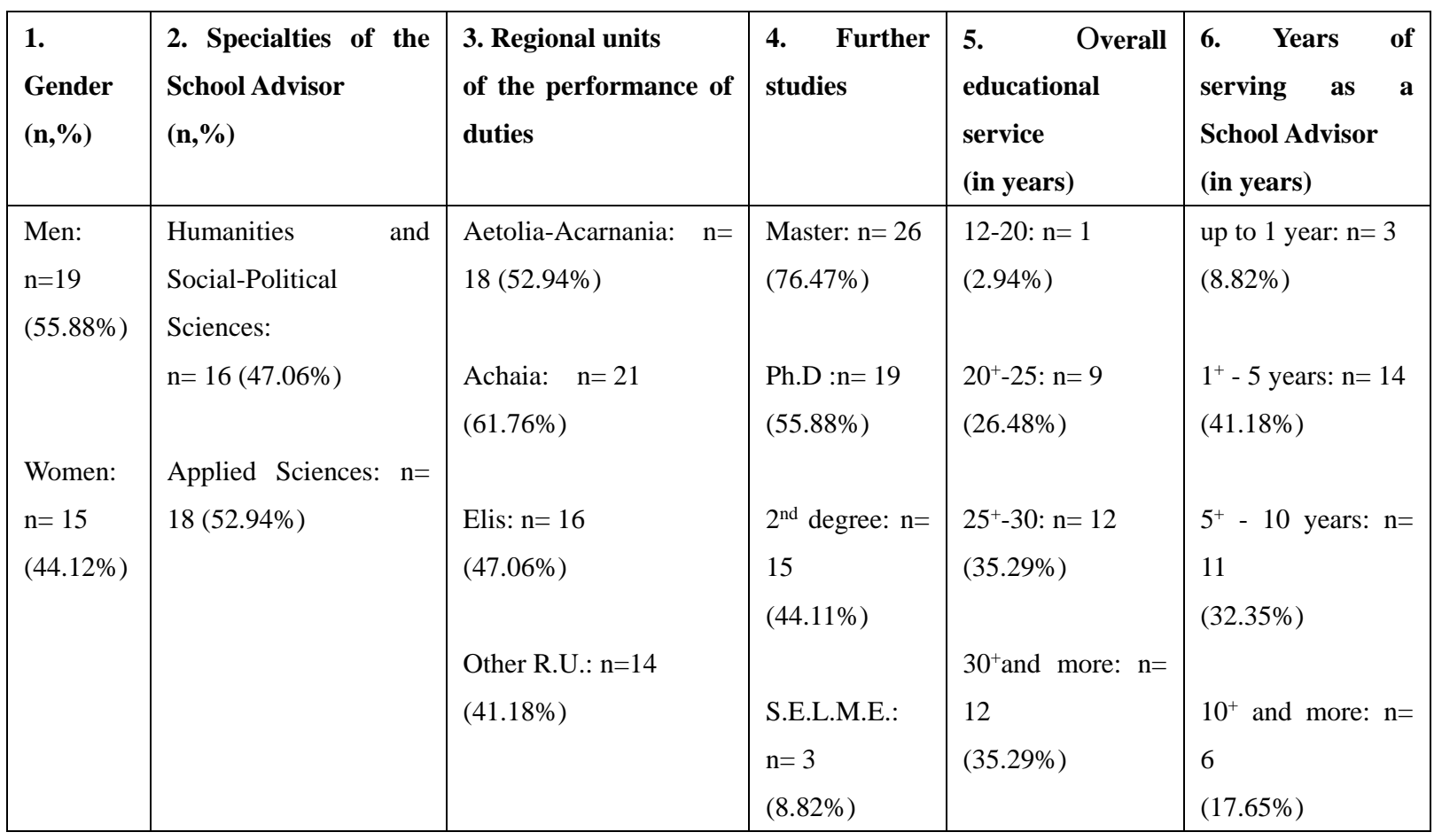

The second part of the questionnaire concerned the main questions and consisted of eight (8) open-ended questions in total as follows:

Question 1st: a. "It is well-known that all the choices of secondary education School Advisors have been made within a different institutional context. How do you consider this fact?"

b. "Based on your experience, what recommendations would you make to improve the selection system of School Advisors?"

Question 2nd: a. "How do you perceive the professional development of teachers?" 
b. "What actions do you undertake for this purpose?"

c. "What suggestions would you make for teachers' training and professional development?"

Question 3rd: "How would you describe your collaboration with teachers in your responsibility in terms of: a) their receptivity, b) frequency of communication, and c) their feedback on your work?"

Question 4th: "Describe your cooperation with other education officials with regard to the guiding work you offer teachers, namely:

a. School Principals

b. Education Directors

c. Regional Director of Education

d. Head of Scientific and Pedagogical Guidance

e. Your fellow School Advisors".

Question 5th: "What is your opinion about the evaluation of teachers and the educational work performed at school in general? Do you believe that it is part of your jurisdiction? Justify your opinion."

Question 6th: "Are you aware of the recent views postulated by O.L.M.E. (Greek Federation of Secondary State School Teachers) on the role of School Advisors at school? What is your opinion about these views?".

Question 7th: "What parts of your work do you consider to be the most important?".

Question 8th: "Formulate an overall evaluation of your experience as a School Advisor."

\section{Results}

As regards the first question (question 1a), there was a negative valuation on the part of School Advisors concerning the changes that have taken place so far in the institutional framework of their choice, both at the level of the central educational planning and in relation to their individual targets (27 references: 69,20\%). As for their suggestions about the improvement of the selection system (1b question), their criticism was focused on how the interview functioned, on the grounds that at times it has sparked a great deal of controversy over the selection of education officials. More specifically, in eleven (11) references (14.67\%), School Advisors assessed positively the function of the interview, provided that compliance with ethics in its use is witnessed. However, in an approximately equal number of references (10 references: 13.33\%), its role as a selection criterion was strongly questioned, since it contains -according to School Advisors- not only subjectivity but also expediency and self-interest, as a result, highly-qualified candidates were sometimes ruled out. Moreover, the behavior of members of the selection board towards School Advisor applicants was commented negatively.

In general, their suggestions lied on stable variables that ensure objective judgment, such as 
qualifications (13 references: $17.33 \%$ ), the special abilities required in specific sectors (10 references: $13.33 \%$ ), written exams (7 references: $9.33 \%$ ) and the periodic evaluation of the candidates for the School Advisors' position (8 references: 10.66\%). Regarding the delineation of teachers' professional development on the part of School Advisors (question 2a), most references laid emphasis on the need for constant and permanent information of teachers on a variety of issues on the school premises (18 references: 20.69\%), their mastering the basic teaching principles and methodology of subjects (15 references: $17.24 \%$ ), the achievement of continuous improvement and efficiency at school (14 references: 16.09\%), their ability to handle effectively the classroom (9 references: 10.34\%), the personalized support of the teachers (7 references: $8.04 \%$ ).

Regarding the delineation of teachers' professional development on the part of School Advisors (second question), most references focused on (a) the need for teachers' constant and permanent updating on a variety of issues arising from the school (18 references: $20.69 \%$ ), (b) their holding the basic teaching principles and methodology of subjects (15 references: $17.24 \%$ ), (c) the achievement of continuous improvement and efficiency at school (14 references: $16.09 \%$ ), (d) the ability to effectively manage the classroom (9 references: $10.34 \%$ ), and (e) the personalized support of teachers ( 7 references: $8.04 \%$ ).

In connection with their activities in support of the teachers' professional development (question 2b), the vast majority of School Advisors (31 references: 30.09\%) attend seminars in response to their institutionally defined role. Visits to schools (10 references: $9.71 \%$ ), electronic communication (8 references: $7.77 \%$ ), workshops (8 references: $7.77 \%$ ), the attendance or organization of model teaching sessions (6 references: $5.83 \%$ ) and personal discussions with teachers in their responsibility (7 references: 6.80\%) are included in the actions accompanying their supportive and guiding role.

The suggestions of School Advisors for training and professional development (question 2c) did not only touch on the expression of specific opinions, but also integrated some references to problems permeating the performance of their task and role. Thus, with respect to their suggestions, they stressed the need for activating official bodies for the training and professional development (e.g.: Regional Training Centers, Institute of Educational Policy, Laboratory Centers of Natural Sciences, Higher Education Institutions) (10 references: $17.20 \%$ ). They were not at all hesitant, however, to acknowledge the personal responsibility of teachers to make provision for it by themselves, in the framework of the potentials for self-education (12 references: $20.70 \%$ ).

As far as the training and career development are concerned, several important problems were stated. Among these, the critique they exerted on the policy of the educational changes and reforms planned by the government, the opposition raised by trade union leaders, the shortage of an organized guidance and support system for School Advisors and the dearth of resources they are confronted with in the performance of their educational role (2 reviews: $10.53 \%$ ) are worth mentioning. Lastly, the lack of time to complete their work (3 references: $15.80 \%$ ) was also remarked.

The question on the cooperation of School Advisors with teachers in their responsibility 
involved qualitative and quantitative characteristics, highlighting the difficulty -in many cases- in this kind of communication. Regarding the qualitative data of communication, that is, the teachers' receptivity and the feedback on the work of School Advisors (questions 3a and $3 \mathrm{c}$ respectively), their answers echoed more skepticism, since, although a significant number of them were positive (50\%), reservations and concerns were still raised in terms of the effectiveness of this cooperation. With regard to receptivity, fifteen (15) of them answered that the receptivity of teachers is strongly positive $(44.12 \%)$, while the remaining seventeen (17) described receptivity as positive but with many limitations and problems (50\%). Lastly, two (2) School Advisors did not answer (5.88\%).

In this question, the participants pointed out specific parameters involved in communication with teachers, often creating problematic situations. Thus, in five (5) references, it was underscored that the framework of receptivity is significantly determined by the years of the teachers' service, with the "seniors" appearing to be less receptive. In three (3) references, School Advisors stressed that the receptivity of teachers has changed in recent years, and that it is not so spontaneous, because the impending evaluation regulates, in many cases, may affect their attitude. In two (2) references, it was underlined that the established perceptions about teaching and the infrequent contact with them are responsible for low receptivity.

Other parameters that determine teachers' receptivity are resistance to novelty and in general to change, the lack of interest on teachers' part, the workload, the personality of the colleagues itself, the "resistance to anything institutional" (code. 26) as was characteristically stated the lack of feedback as well as the bombardment and dissemination of knowledge that limit the role of School Advisors as knowledge carriers for teachers.

In connection with the feedback on their work, in twenty-four (24) references, feedback was recorded uninhibitedly as extant (70.60\%), nine (9) did not make any comment on it whatsoever (26.50\%), while only one (1) School Advisor described it as non-existent due to his inability to move $(2.90 \%)$. Indeed, through criterion $\mathrm{x} 2$, the statistical analysis demonstrated that feedback is associated with gender (male), specialty (science), the long-lasting educational service of School Advisors and their great experience in the performance of their tasks (see: Table 2).

With regard to the frequency of communication of School Advisors with teachers in their responsibility (question 3b), ten (10) School Advisors stressed that their communication with teachers is frequent $(29.40 \%)$, nine (9) claimed that it is little to minimum (26.50\%), while eight (8) said that communication is very frequent, almost on a monthly basis $(23.50 \%)$. It seemed that it was statistically correlated with the overall educational service of School Advisors. School Advisors with more educational service appear to communicate with teachers more often (see Table 2).

The fourth question concerned the cooperation of School Advisors with other education officials. Hence, with respect to the school principals, in twenty two (22) references, a very good relationship was recorded without any problems (64.69\%), especially with those principals who had appertained to the pedagogical guidance of School Advisors. Nevertheless, in nine (9) references, School Advisors pointed out problems in their relationships with the 
school principals $(26.46 \%)$. These problems were linked to the lack of Heads' responsiveness to their duties, the fear because of the upcoming evaluation the dissatisfaction expressed with the disruption induced in schools when teachers participate in meetings with School Advisors. One (1) School Advisor said that he has not formed a well-rounded opinion yet (2.95\%).

In relation to Education Directors, in fifteen (15) references, it was accentuated that the cooperation of School Advisors with them was good, without any problems (44.11\%), in seven (7), it was characterized as official and formal (20.59\%), while in six (6) references, the occurrence of frictions or dysfunctions was underscored (17.65\%). Male School Advisors were proven to have developed a better relationship with them. Additionally, five (5) School Advisors did not respond to this question (14.70\%). Regarding the dysfunctional cooperation of School Advisors with Education Directors, the former alluded to the lack of secretarial support on the part of the latter, to some frictions, which were not further clarified, and even to a sort of disaffection between them.

As concerns the framework of cooperation of School Advisors with the Regional Education Director, their views appeared almost equally divided into the relationship being very good on the one hand (15 references: $44.11 \%$ ) and more formal and official on the other (12 references: $35.29 \%$ ). Six (6) School Advisors did not make reference to this cooperation $(17.65 \%)$.

More substantial and systematic is said to be the relationship of the sample of School Advisors with the Head of Scientific and Pedagogical Guidance. In twenty four (24) references, the level of cooperation was considered to be good and systematic in terms of the organization of training courses or even matters of information or guidance of School Advisors (70.58\%). In seven (7) references, the relationship was characterized as formal (20.59\%). Two (2) School Advisors did not give any feedback on that (5.88\%).

Cooperation among School Advisors was commented with more reservations, though. More specifically, in fifteen (15) references, School Advisors stated that there are no problems in their cooperation and that the atmosphere among them is good (44.11\%). However, in the same number of references (15), School Advisors appeared quite concerned about the context of their cooperation and put emphasis on some specific parameters, which influence and define this framework (44.11\%), such as the relatively low frequency of communication, which they are not satisfied with, its ineffectiveness in solving problems or in the adoption of solutions within school, the selectivity of this communication with specific specialties of School Advisors or with colleagues with similar personal characteristics. Finally, three (3) School Advisors did not mention the issue of the cooperation among them $(8.83 \%)$.

When asked about their opinion on the evaluation of teachers and the educational work in general (5th question), the majority of the sample (16 references: $47.05 \%$ ) considered that the evaluation falls into the responsibility of School Advisors, but concurrently, preconditions and reservations were expressed about its implementation (mostly by male school advisors), which should be taken into account, ensuring its validity and reliability.

Thus, in six (6) references, it was stressed that the evaluation should be disconnected from 
any pay increment for teachers and should not be associated with promotion quotas or wage fixation, as the relevant Law 4024/2011 provisioned (Article 7). In three (3) references, they brought attention to the fact that evaluation should be combined either with the proper preparation of the body of School Advisors (through training or a general competence) or with a general redefinition of their role and the way of their selection. In three (3) references, the objectivity of the criteria as well as the development of a climate of trust between teachers and School Advisors were underlined as key requirements for the evaluation. In three (3) references, the State's instability in this sector, which does not give rise to a positive result was emphasized. Finally, one (1) School Advisor noted that "if we had reliable mechanisms, it would not be unadvisable that the Advisor assesses, in the sense of giving a valid opinion on what is happening with the colleague" (cod. 34). Additionally, five (5) School Advisors stated that it is not possible that the School Advisor exercises evaluation duties as well, as this would gradually bring about a distortion in their role which should remain purely advisory, or on account of other particular problems (14.70\%). Nine (9) School Advisors strongly supported evaluation, considering that it forms an integral part of their responsibilities (26.47\%). Two (2) School Advisors said they could not take a clear position, because there are arguments and counter arguments on this matter, making their voicing an opinion unlikely (5.89\%). Finally, two (2) School Advisors did not pass judgement on that (5.89\%).

The sixth (6th) question was related to the views of School Advisors about the positions of O.L.M.E. in connection with their role. As for the first sub-question, twenty three (23) School Advisors said that they are conscious of them (67.65\%), whereas nine (9) said they are not (26.47\%). Two (2) School Advisors did not do any appraisal (5.88\%). In relation to the criticism on these positions, in sixteen (16) references (69.56\%), School Advisors adopted a negative position not only on the policy of O.L.M.E. in relation to the institutional role of the School Advisor, but also on its general educational policy over the last four years. In (4) references, O.L.M.E.'s attitude was regarded as positive and justifiable (17.40\%).

It is worth noting that in this question, the School Advisors of the sample somehow narrowed down their responses to the issue of the evaluation of the school work primarily, to which O.L.M.E. raised serious objections in terms of the role and involvement of School Advisors at the period of conducting the survey. Their answers were almost solely concerned with this particular parameter. School Advisors who vindicated the positions of O.L.M.E. pointed out that the reluctance of O.L.M.E. is justified, since guarantees for the purpose of evaluation provided by the State -which does not work with a view to improving the school- are completely lacking. At the same time, the recurrence to "inspectionism" -as noted- activates the reflexes of the trade union movement as a reaction. Finally, three (3) School Advisors did not respond to this question at all (13.04\%). The statistical analysis of the responses showed that School Advisors with many years of educational experience are better informed about the positions of O.L.M.E. and, concurrently, expressed the strongest reservations about it, as well (see Table 2).

In the 7th question, most references laid emphasis on the provision of their training project for teachers (13 references: 23.63\%) as well as their emotional support (11 references: $20.00 \%$ ). Moreover, one (1) significant parameter mentioned was the pedagogical guidance 
of teachers ( 7 references: $12.73 \%$ ). In five (5) references, their interpersonal communication with teachers was spotlighted $(9.09 \%)$, through which their work is fueled. Four (4) references were made to the possibility of School Advisors to solve problems and the teaching support of teachers in the particular subjects of their specialty alike (7.28\%). Fewer references concentrated on the potential of School Advisors to facilitate the development of cooperation among teachers (3 references: $5.46 \%$ ), on the climate of trust between teachers and School Advisors which is essential for their cooperation (3 references), and on the feedback on the educational work (2 references: $3.64 \%$ ). To conclude, one (1) reference brought out the writing work of the School Advisor and the support of teachers in terms of classroom management (1.81\%). One (1) School Advisor did not answer that question.

The last question of the interview (question: 8) was reflective. School Advisors were invited to give a general assessment of this position based on their previous experience. Accordingly, in twenty-two (22) references $(64.70 \%)$, their involvement with the institution was positively assessed, while there were concomitantly several allusions to a plethora of problems accompanying the performance of their role. In seven (7) references $(20.60 \%)$, the valuation was absolutely positive. Three (3) School Advisors felt frustrated by the institution (8.82\%), describing their experience as negative. In fact, one of them does not consider the existence of the institution to be necessary, and two (2) School Advisors did not offer an answer to this question $(5.88 \%)$. The statistical analysis demonstrated that School Advisors who had greater educational service and greater experience in the institution were more concerned and worried (see Table 2).

As noted previously, in twenty-two (22) references, the exercise of the role on the part of the participant School Advisors was positively assessed. However, this was accompanied by the specification of certain problems and mainly concerned four (4) parameters: 1) the lack of the institution's support by the State itself (7 references), 2) the excessive number of teachers whom School Advisors supervise and guide (5 references), 3) the negative impact of the recent legislative regulations about teachers' evaluation on the institutional role (4 references), 4) the assignment of administrative-bureaucratic obligations to them in the context of the performance of their duties (4 references). Actually, in three (3) references, School Advisors underscored the lack of financial resources -even for training purposes- as a major difficulty in the exercise of their role. Two (2) references stressed that the effective exercise of their duties would require an initial systematic training as well as continuous training. They characteristically stated:

" The role is absolutely integrated into the Greek educational system, meaning that it abounds in good intentions and very low performance. The performance is so low because too many things are missing. Lack of hours, resources, opportunities."(cod. 25).

What is more, among the problems associated with the performance of their duties, the following were listed: the absence of feedback on their work, the distrust in the institution, the absence of a specific time schedule, the multitude of educational models which creates confusion even to them, trade union attachments, the numerous shortages remote schools have, the dependence on the dominant educational policy, the vested interests and the lack of 
a common strategy among School Advisors, leading to the success of the institution relying solely on the goodwill of each School Advisor (1 reference).

In contrast with these problems mentioned above, the School Advisors of the sample suggested specific solutions, among which it is worthwhile to mention their systematic and regular training, the limitation of the operational framework of their duties in their educative and guiding role, the moral and economic rehabilitation of School Advisors, their ability to make avail of the potentials of their educational responsibility, the allocation of financial resources, the reformation of the institutional framework and the focus of their efforts to create a climate of mutual trust between School Advisors and teachers. As indicatively specified:

" This lack of confidence is existent, yet plausible, because those who hold some positions cannot see the other as an essential part of education, but as an instrument with which they will do their work."(Cod. 32).

Table 2 depicts the correlations of the answers to the questions with the demographic characteristics of the sample.

Table 2. Correlation of the demographic characteristics of the sample with the respondents' answers

\begin{tabular}{|c|c|c|c|c|}
\hline Questions & Findings & Responses $(\mathbf{N})$ & Responses $(\%)$ & $\begin{array}{l}\text { Statistical } \\
\text { analysis } \\
\text { (correlations) }\end{array}$ \\
\hline $\begin{array}{l}\text { Q3b. "How would you } \\
\text { describe your } \\
\text { collaboration with } \\
\text { teachers in your } \\
\text { responsibility in terms of } \\
\text { frequency of } \\
\text { communication" }\end{array}$ & $\begin{array}{l}\text { a. Frequent (1 to } 5 \\
\text { times yearly) } \\
\text { b. Little to very little } \\
\text { c. Very frequent }\end{array}$ & $\begin{array}{l}\text { a. } 10 \text { references } \\
\text { b. } 9 \text { references } \\
\text { c. } 8 \text { references }\end{array}$ & $\begin{array}{l}\text { a. } 29,40 \% \\
\text { b. } 26,50 \% \\
\text { c. } 23,50 \%\end{array}$ & $\begin{array}{l}\text { Correlation in terms } \\
\text { of the total } \\
\text { educational service } \\
\text { of School Advisors } \\
\left(x^{2}=3,000, \quad d f=1,\right. \\
p=0,083)\end{array}$ \\
\hline $\begin{array}{l}\text { Q3c. «How would you } \\
\text { describe your } \\
\text { collaboration with } \\
\text { teachers in your } \\
\text { responsibility in terms of } \\
\text { their feedback on your } \\
\text { work?" }\end{array}$ & Highly positive & 24 references & $70,60 \%$ & $\begin{array}{l}\text { Statistically } \\
\text { significant correlation } \\
\text { with regard to the } \\
\text { four variables } \\
\text { a. Sex } \quad\left(\chi^{2}=0,586 \text {, }\right. \\
\text { df }=1, p=0,444) \\
\text { b. } \quad \text { Specialty } \\
\left(\chi^{2}=0,818,\right. \\
\text { p=0,366) } \mathrm{df}=1 \text {, } \\
\text { c. } \quad\left(\chi^{2}=0,524,\right. \\
\text { service } \\
\text { df }=1, p=0,405) \\
\text { d. } \text { Service }\left(x^{2}=0,818,\right. \\
\text { df }=1, p=0,366)\end{array}$ \\
\hline
\end{tabular}




\begin{tabular}{|c|c|c|c|c|}
\hline $\begin{array}{l}\text { Q4b. "Describe your } \\
\text { cooperation with other } \\
\text { education officials with } \\
\text { regard to the guiding } \\
\text { work you offer teachers, } \\
\text { namely Education } \\
\text { Directors" }\end{array}$ & $\begin{array}{l}\text { a. Very good, } \\
\text { without problems } \\
\text { b. Formal } \\
\text { c. Problematic }\end{array}$ & $\begin{array}{l}\text { a. } 15 \text { references } \\
\text { b. } 7 \text { references } \\
\text { c. } 6 \text { references }\end{array}$ & $\begin{array}{l}\text { a. } 44,11 \% \\
\text { b. } 20,59 \% \\
\text { c. } 17,65 \%\end{array}$ & $\begin{array}{l}\text { Statistically } \\
\text { significant correlation } \\
\text { in terms of the sex of } \\
\text { School Advisors } \\
\left(x^{2}=5,867, \quad d f=1,\right. \\
p=0,15)\end{array}$ \\
\hline $\begin{array}{l}\text { Q5. "What is your } \\
\text { opinion about the } \\
\text { evaluation of teachers } \\
\text { and the educational work } \\
\text { performed at school in } \\
\text { general? Do you believe } \\
\text { that it is part of your } \\
\text { jurisdiction? Justify your } \\
\text { opinion." }\end{array}$ & $\begin{array}{l}\text { a. Positive, under } \\
\text { conditions } \\
\text { b. Positive }\end{array}$ & $\begin{array}{l}\text { a. } 16 \text { references } \\
\text { b. } 9 \text { references }\end{array}$ & $\begin{array}{l}\text { a. } \quad 47,05 \% \\
\text { b. } 26,74 \%\end{array}$ & $\begin{array}{l}\text { Statistically } \\
\text { significant correlation } \\
\text { in terms of the sex of } \\
\text { School Advisors } \\
\left(x^{2}=4,265, \quad d f=1,\right. \\
p=0,039)\end{array}$ \\
\hline $\begin{array}{l}\text { Q6a. "Are you aware of } \\
\text { the recent views } \\
\text { postulated by O.L.M.E. }{ }^{1} \\
\text { on the role of School } \\
\text { Advisors at school?" }\end{array}$ & Positive & 23 references & $67,65 \%$ & $\begin{array}{l}\text { Statistically } \\
\text { significant correlation } \\
\text { in terms of the total } \\
\text { educational service } \\
\text { of School Advisors } \\
\left(x^{2}=7,311, \quad d f=1 \text {, }\right. \\
p=0,007)\end{array}$ \\
\hline $\begin{array}{l}\text { Q6b. "What is your } \\
\text { opinion about these } \\
\text { views?" }\end{array}$ & Negative & 16 references & $69,56 \%$ & $\begin{array}{l}\text { Statistically } \\
\text { significant correlation } \\
\text { in terms of the total } \\
\text { educational service } \\
\text { of School Advisors } \\
\left(x^{2}=1,250, \quad d f-=1 \text {, }\right. \\
p=0,264)\end{array}$ \\
\hline $\begin{array}{l}\text { Q8. "Formulate an } \\
\text { overall evaluation of } \\
\text { your experience as a } \\
\text { School Advisor" }\end{array}$ & $\begin{array}{l}\text { a. Positive with } \\
\text { problems } \\
\text { b. Absolutely positive }\end{array}$ & $\begin{array}{l}\text { a. } 22 \text { references } \\
\text { b. } 7 \text { references }\end{array}$ & $\begin{array}{l}\text { a. } 64,70 \% \\
\text { b. } 20,60 \%\end{array}$ & $\begin{array}{l}\text { Statistically } \\
\text { significant correlation } \\
\text { in terms of the total } \\
\text { educational service } \\
\text { of School Advisors } \\
\text { and the years of } \\
\text { their duty exercise } \\
\text { a. Educational } \\
\text { service } \quad\left(x^{2}=1,505 \text {, }\right. \\
\text { df }=1, p=0,220) \\
\text { b. Service }\left(x^{2}=3,310 \text {, }\right.\end{array}$ \\
\hline
\end{tabular}

OLME : Greek Federation of Secondary State School Teachers 
$\mathrm{df}=1, \mathrm{p}=0,069$

\section{Discussion and Conclusion}

Based on our research data, it is ascertained that the School Advisors of our sample did not only postulate their positions on the issues under investigation, but also expressed personal opinions, judgments and often critique, perceiving the interview as a reflection-doing agent on their side on issues related to their guiding role and in the teachers' professional development and their broader educational work. Subsequently, with regard to all the questions raised in this piece of work, they expressed strong reservations and doubts pervading the entire range of their positions. Moreover, it should be noted that the views of the sample of School Advisors are of particular importance, given that the majority $(n=24)$ had a great overall educational experience (over 25 years), having reached a holistic view of the educational issues on which they took a stand.

More analytically, the positions of the School Advisors of the sample regarding the frequent changes that have been put into practice in the institutional framework of their selection, reveals precisely this lack of confidence they receive on the part of the state. Thus, they referred to a negative change, which undermines both the credibility of the institutions and their personal targets. This is a negative development, which many described as intentional, induced, which does not form a framework of meritocratic functioning of institutions and, in particular, an organized, wisely targeted and purposeful educational planning. It should be cited that, with regard to the proposals they conveyed, the exercise of criticism on the function of the interview is looked on as expected, on account of the fact that it has been strongly challenged for its role in the selection of education officials and certainly the School Advisors' body.

Regarding to the Greek educational reality, the positions of the School Advisors of the sample revealed that the professional development of teachers is an important dimension of their role, to which all actions they develop lead. More specifically, according to the vast majority of School Advisors (47 references: 54.02\%), it appears that the professional development of secondary education teachers in Greece follows international trends for a permanent redefinition of the teachers on the basis of modern educational data, the latest developments in their subjects, but also the requirement for the effectiveness of schools.

The views they expressed on the bestowal of meaning to the term "professional development" show that it is perceived in a twofold way, that is, as a continuous development (personal and professional) in the society of knowledge and information, but also as a necessity of the teachers' competence in the teaching practice and methodology of the subjects they teach in school. It is an approach to professional development, in which elements of a more traditional idea are incorporated, linking the course of the teachers' development to the school function and the effectiveness of the educational act. Hence, this would support the view that the way in which the School Advisors bestow meaning to the professional development of teachers is completely consistent with the character of the Greek educational system, which is imbued with normative standards in the teaching of subjects that are closely related to the school effectiveness and less connected with the autonomy of teachers to determine the educational 
content of subjects, to transform their practices and to contemplate critically upon them (Guskay, 2014; Jones \& Jones, 2013; Salteris, 2006).

As regards the content of the programs for teachers' professional development, the articulated opinions of School Advisors of the sample exhume the necessity for connecting training with the function of school, its peculiar culture and the emerging needs of teachers to be constantly activated in it. Besides, these proposals also intersect with the training needs of the teachers themselves which are identified through many researches (see: Bagakis, 2015; Frangoulis \& Valkanos, 2011; Ifanti, 2014; Ifanti \& Vozaitis, 2007).

Considering that during the period in which the interviews were carried out self-evaluation processes of the educational work of schools had been conducted (see: Ministerial Decision ГI/30972/15-03-2013 "Evaluation of the Educational Work of School Self-Assessment Process"), it may seem paradoxical that none of the School Advisors from the sample referred to the relevant procedures which, under certain circumstances, can contribute to the professional development of teachers. This may be attributed either to a general wariness of School Advisors toward the relevant procedures, which caused chain reactions, since they are considered as policies mainly presaging the individual evaluation of teachers, or to a lack of the corresponding alertness from their part to get involved in school self-evaluation, in which their role would be reminiscent of the critical supporter. The question on the cooperation of School Advisors with teachers in their educational responsibility entailed qualitative and quantitative characteristics, highlighting the difficulty of this kind of communication.

The cooperation of School Advisors with other education officials shed light on the existing gap between the administrative and guiding framework of the operation of supportive education structures as well as the lack of general cooperation among School Advisors, which they mainly expressed dissatisfaction with. The lack of general cooperation with education managing directors (i.e.: Head of Directorates and Regional Education Directors) may be due to a common reluctance on the part of School Advisors to be entrusted with administrative work, as clearly echoed in a pertinent point of view: "The School Advisor must be in the qualitative dimension of the issues ... not be converted into an administration head"(cod. 01). The lack of cooperation from the other part is a great concern with regard to the effectiveness of the practices adopted by the education officials, especially at a time when cooperative relations are projected as a prerequisite for improving education and an effective and sustainable professional development of teachers (see: Darling-Hammond \& McLaughlin, 1995; Garet et al., 2001; Giakoumi \& Theophilidis, 2012).

Regarding the evaluation of teachers and the educational work in general, the views expressed seem to be fairly led to the same conclusion, encapsulated in the coexistence of the acceptance of evaluation in its conception and distrust in terms of its implementation. The promoted evaluation policies seemed to concern the participant School Advisors, on the grounds that evaluation was mentioned as a component which affects their work or will obviously affect it in the future.

In connection with the attitude of School Advisors towards the positions of the Federation of Secondary School Teachers (O.L.M.E.), School Advisors appeared quite distanced from the 
overall policy of the Federation, focusing their critique on its practices, aiming at the satisfaction of corporate interests mainly. Thus, the attitude of O.L.M.E. (particularly in relation to the issue of evaluation) seems to be deemed as ineffective by the surveyed School Advisors, unable to contribute to an overall strategy for the effective operation of the educational system.

This reservation expressed by School Advisors of the sample about the role of O.L.M.E. may be attributed to a general weakening of the institutional role of trade unions in decision-making practices as it was recently supported in another study (Blackcap, 2013: 43). Moreover, it could be linked to the absence of a strong collaborative culture as pointed out by the respondents.

According to School Advisors' views, with reference to the most important aspect of their work, the dedication of the training role they exercise, enhancing the professional development of teachers, appears to be universally attested in the sample. Besides this, the advisory-consultative and emotional support they offer teachers is thought of as notable by them. In consequence, the interpersonal communication of teachers and School Advisors appears to emerge as an important component of their work, even though it is tested by a variety of problems, as reflected in the last question (8th) of the School Advisors' interviews.

A large percentage of the sample (73.52\%) appeared quite preoccupied with the performance of their role and tasks, although several of them provided a positive assessment of the progress and presence of the institution in the education system.

As regards the correlation between demographic characteristics to the responses of the participants in our research, it is worth noting that the parameter of the overall educational service and experience in performing the tasks of School Advisor seems to differentiate the answers. The longer the educational service and experience in the institution is held, the more they communicate with teachers, the greater feedback they receive from communicating with them, the better they are informed about the positions of O.L.M.E. At the same time, they are more cautious and skeptical about both its policy and the performance of their duties. Therefore, the experience from the involvement of School Advisors in the institution is brought out as a catalyst of the articulated positions.

In addition, the gender variable also seems to differentiate the views of the sample. More specifically, male School Advisors receive stronger feedback from their communication with teachers, develop a better relationship with Education Directors, while they raise more intense objections to the implementation of evaluation. Furthermore, School Advisors in science receive stronger feedback.

Summing up, it seems that the School Advisors of our sample emphatically stress the importance of their role in the professional support and development of teachers of secondary education, linking it, however, to the enumeration of problems which, in their opinion, afflict the institution over time. The problems listed by the School Advisors of the sample determine precisely the parameters associated with their guiding work and shape the framework of the function of the institution itself and of the teachers' professional development. Consequently, 
to the extent the institutional fulfillment drawn from the exercise of the role of School Advisors seems to be related to problem solving, then their proposals can additionally be considered as preconditions of successful evolution and further development of the institution. Apart from this, at a time when a new redefinition of the role of education officials is sought, the use of the lived experience of School Advisors may contribute massively to the planning of policies for the improvement of school. To that end, their institutional support could help strengthen the culture and the supportive school structures, as well as the professional development of secondary education teachers in Greece. These findings might also contribute to a wider investigation and further discussion on this topic in other countries as well, especially in those which employ centralised policies in their educational matters.

\section{Acknowledgments}

Each author jointly contributed in the preparation of this paper. All authors have seen and approved the final version.

\section{References}

Aas, M. (2016). Leaders as learners: developing new leadership practices. Professional Development in Education, 43(3). 439-453.

Avalos, B. (2011). Teacher professional development in teaching and teacher education over ten years. Teaching and Teacher Education, 27, 10-20. https://doi.org/10.1016/j.tate.2010.08.007

Bagakis, G. (2015). Pros anazitisi ethikis stratigikis gia politikes epimorfosis (Looking for a national strategy for training policies,), in: Bagakis, G. \& Skia, K. (Eds.) Diereunisi ton dynatotiton epimorfosis ton ekpaideutikon simera sti hora mas (Investigating the possibilities of training teachers today in our country) (pp. 117-132). Athens: Grigoris, (in Greek).

Beijaard, D., Meijer, P., \& Verloop, N. (2004). Reconsidering research on teachers' professional identity. Teacher and Teacher Education, 20(2). 107-128. https://doi.org/10.1016/j.tate.2003.07.001

Blackcap, J. (2013). Ekpaideutikos sindicalismos kai allages sto rolo tou ekpaideutikou (Educational syndicalism and changes in the role of the teacher). Nea Paideia (New Education), 148. 39-49 (in Greek).

Bubb, S., \& Earley, P. (2010). Helping staff develop in schools. London: Sage

Bush, T. (2009). Leadership development and school improvement: contemporary issues in leadership development. Educational Review, 61(4).375-389. https://doi.org/10.1080/00131910903403956

Cohen, L., Manion, L., \& Morrison, K. (2008). Methodologia ekpaideutikis erevnas (Methodology of educational research). Athens: Metaihmio (in Greek).

Darling Hammond, L., \& McLaughlin, M.W. (1995). Policies that support professional development in an era of reform. Phi Delta Kappan, 76 (8), pp. 597-604. 
Day, C., Kington, A., Stobart, G., \& Sammons, P. (2006). The personal and professional selves of teachers: stable and unstable identities. British Educational Research Journal, 32(4). 601-616. https://doi.org/10.1080/01411920600775316

Davies, B., \& Ellison, L. (2001). School leadership for the 21th century, a competency and knowledge approach. London: Routledge.

Fragoulis, I., \& Balkanos, E. (2011). Dierevnisi apopseon ton ekpaideutikon gia ton tropo epimorfosis tous sto Perifereiako Epimorfotiko Kentro Patras (Investigation of the views of teachers on how to train them at the Regional Education Center of Patras), in: Economidis, B. (Eds.) Ekpaideusi kai epimorfosi ekpaidetikon: theoritikes kai erevnitikes proseggisis (Teachers' Education and in-service Training: theoretical and research approaches) (pp. 736-775). Athens: Pedio (in Greek).

Flores, M. A., \& Day, C. (2006). Contexts which shape and reshape new teachers' identities: a multi-perspective study. Teaching and Teacher Education, 22(2). 219-232. https://doi.org/10.1016/j.tate.2005.09.002

Fullan, M. (2001). Leading in a culture of change. San Francisco: Jossey-Bass.

Garet, M. S., Porter, A. C., Desimone, L, Birman, B. F., \& Yoon, K. S. (2001). What makes professional development effective? Results from a national sample of teachers. American Educational Research Journal, 38(4). 915-945. https://doi.org/10.3102/00028312038004915

Giakoumi, S., \& Theophilidis, X. (2012). He synergatiki koultoura os ipostiriktiko ergaleio sto ergo tou ekpaideutikou (The collaborative culture as a supportive tool in the work of the teacher), sto: 12o Synedrio tis Paidagogikis Etairias Kyprou (12th Conference of the Cyprus Pedagogical Society), 475-483, [Online] Available: http: //ww.pek.org.cy, (May 5, 2017) (in Greek).

Guskay, T. R. (2014). Planning professional learning. Educational Leadership, 71(8). 10-17.

Hilferty, F. (2008). Theorising teacher professionalism as an enacted discourse of power. British Journal of Sociology of Education, 29(2). 161-173. https://doi.org/10.1080/01425690701837521

Ifanti, A. A. (1994). Education politics and the Teachers Unions in Greece. European Journal of Teacher Education, 17(3). 219-230. https://doi.org/10.1080/0261976940170307

Ifanti, A. A. (2009). Attempts to empower schools in the Greek educational system. In A. Nir (Eds) Centralization and school empowerment. From rhetoric to practice. (pp. 107-119) New York: Nova Science Publishers.

Ifanti, A. A. (2014). Epimorfosi kai epaggelmatiki anaptyxi ton ekpaideutikon. Politikes kai praktikes stin Ellada (In-service training and professional development of teachers. Policies and practices in Greece). Athens: Diadrasi (in Greek).

Ifanti, A. A., \& Fotopoulou, V. S. (2011). Teachers' perceptions of professionalism and professional development. A case study in Greece. Word Journal of Education, 1(1). 40-51. 
Ifanti, A. A., \& Vozaitis, Г. (2007). Epaggelmatiki anaptyxi ekpaideutikon kai epimorfosi: to paradeigma ekpaideutikon deuterovathmias ekpaideusis tis A perifereias tou nomou Axaias (Professional development of teachers and in-service training: the example of secondary education teachers of the first region of the prefecture of Achaia), Dioikitiki Enimerosi (Administrative Forum), 40. 87-105 (in Greek).

Jones, J., \& Jones, K. A. (2013). Teaching reflective practice: Implementation in the teacher-education setting. The Teacher Educator, 48(1). 73-85. https://doi.org/10.1080/08878730.2012.740153

Kelchtermans, G. (2005). Teachers' emotions in educational reforms: self-understanding, vulnerable commitment and micro-political literacy. Teacher and Teacher Education, 21(8). 995-1006. https://doi.org/10.1016/j.tate.2005.06.009

Kirk, G. (2004). The chartered teacher: A challenge to the profession in Scotland. Education in the North, 11, 10-17.

Kiriazi, N. (2002). He koinoniologiki erevna, kritiki episkopisi ton methodon kai ton texnikon (Sociological research. Critical review of methods and techniques). Athens: Greek Letters (in Greek).

MacBeath, J., \& Moos, L. (2004). Democratic learning: the challenge to school effectiveness. London: Routledge. https://doi.org/10.4324/9780203352908

MacBeath, J, Schratz, M., Meuret, D., \& Jakobsen, L. (2000). Self-evaluation in european schools: a story of change. London: Routledge. https://doi.org/10.4324/9780203165850

MacGilchrist, B., Reed, J., \& Myers, K. (2008). The intelligent school. London: Sage, 2th edition.

Maslowski, R., Doolaard, S., \& Bosker, R. J. (2008). Much more than the effective classroom: a lifetime of research, evaluation, improvement, and dissemination. School Effectiveness and School Improvement, 19(4). 353-363. https://doi.org/10.1080/09243450802535166

Mason, J. (2003). He diexagogi tis poiotikis erevnas (Conducting qualitative research). Athens: Greek Letters (in Greek).

Pashiardis, P. (2009). Empowering schools in centralized states: experiences from Cyprus, in: Nir, A.(Ed.) Centralization and school empowerment. From rhetoric to practice (pp. 9-29) New York: Nova Science Publishers.

Robson, C. (2007). He erevna tou pragmatikou kosmou (The rea-world research). Athens: Gutenberg (in Greek).

Robinson, V. M. J., \& Timperley, H. S. (2007). The leadership of the improvement of teaching and learning: lessons from initiatives with positive outcomes for students. Australian Journal of Education, 51(3). 247-262. https://doi.org/10.1177/000494410705100303

Salteris, N. (2006). Diarkis ekpaideusi ekpaideutikon: anazitontas ton anastoxastiko epaggelmatia (Teachers' continuing education: looking for the reflective professional). Athens: 
Taxideutis (in Greek).

Schein, E. H. (1992). Organizational culture and leadership. San Francisco: Jossey-Bass.

Sergiovanni, T. J. (1984). Leadership and excellence in schooling. Educational Leadership, 41(5). 6-13.

Shawer, S. (2010). Classroom-level teacher professional development and satisfaction: Teachers learn in the context of classroom-level curriculum development. Professional Development in Education, 36(4). 597-620. https://doi.org/10.1080/19415257.2010.489802

Swann, M., McIntyre, D., Pell, T., Hargreaves, L. \& Cunningham, M. (2010). Teachers' conceptions of teachers' professionalism in England in 2003 and 2006. British Educational Research Journal, 36(4). 549-571. https://doi.org/10.1080/01411920903018083

Tang, S. Y. F., Leung, P. P. W., Chow, A. W. K., \& Wong, P. M. (2010). A case study of teacher learning in an assessment for learning project in Hong Kong. Professional Development in Education, 36(4). 621-636. https://doi.org/10.1080/19415250903554087

York-Barr, J., \& Duke, K. (2004). What do we know about teacher leadership? Findings from two decades of scholarship. Review of Educational Research, 74(3). 255-316. https://doi.org/10.3102/00346543074003255

Vamvoukas, M. (2010). Eisagogi stin psyxopaidagogiki erevna kai methodologia (Introduction to psycho-pedagogical research and methodology), Athens: Grigoris (in Greek).

\section{Copyright Disclaimer}

Copyright for this article is retained by the author(s), with first publication rights granted to the journal.

This is an open-access article distributed under the terms and conditions of the Creative Commons Attribution license (http://creativecommons.org/licenses/by/4.0/). 